\title{
Clinical Trial Non-Investigational Product Supplies Shipment Documentation
}

National Cancer Institute

\section{Source}

National Cancer Institute. Clinical Trial Non-Investigational Product Supplies Shipment

Documentation. NCI Thesaurus. Code C115563.

Records providing information regarding the shipment of supplies being used in a clinical trial that are not related to the investigational product. 